$\begin{array}{rr}\text { JURNAL } & \text { Volume } 14, \text { Nomor 3, Mei 2018 } \\ \text { FIT(1)PATOLOGI } & \text { Halaman } 83-88 \\ \text { I N D O N E IA } & \text { DOI: 10.14692/jfi.14.3.88 } \\ \text { ISSN: 0215-7950 }\end{array}$

\title{
Eksplorasi dan Karakterisasi Khamir dan Bakteri sebagai Agens Antagonis terhadap Penyebab Penyakit Blas pada Padi
}

\author{
Exploration of Yeasts and Bacteria as Antagonist Agent \\ of Rice Blast Pathogen
}

Jauharoh Maknunah, Meity Suradji Sinaga*

Institut Pertanian Bogor, Bogor 16680

\begin{abstract}
ABSTRAK
Penyakit blas (Pyricularia oryzae) merupakan salah satu penyakit utama pada padi yang dapat menyebabkan kerugian mencapai $61 \%$. Salah satu cara pengendalian penyakit blas ialah memanfaatkan agens antagonis, baik khamir maupun bakteri. Penelitian ini bertujuan mendapatkan galur khamir dan bakteri yang berpotensi efektif untuk mengendalikan penyakit blas. Khamir dan bakteri diisolasi dari daun Digitaria sp., Panicum sp., dan Pennisetum sp.. Khamir dan bakteri tersebut diseleksi melalui uji hipersensitif pada daun tembakau, uji tanam langsung pada benih padi 'Ciherang', dan uji hemolisis pada medium agar-agar darah. Galur khamir dan bakteri nonpatogen diuji antagonismenya melalui uji kultur ganda, uji pembentukan senyawa volatil, uji hiperparasitisme, dan uji aktivitas kitinolitik. Tiga jenis khamir (Cryptococcus sp., Rhodotorula sp., dan Candida sp.) dan dua jenis bakteri (Bacillus sp. dan isolat PPY) berpotensi sebagai agens antagonis P. oryzae.
\end{abstract}

Kata kunci: hiperparasitisme, kitinolitik, senyawa volatil, uji hemolisis, uji hipersensitif

\begin{abstract}
Blast disease (Pyricularia oryzae) is a major disease of rice that causes $61 \%$ yield losses. An alternative way to control the disease is applying antagonistic agents, both yeasts and bacteria. This study was aimed to obtain yeast and bacterial isolates that can be used as antagonistic agents to effectively control blast disease. Yeasts and bacteria were isolated from the leaves of Digitaria sp., Panicum sp., and Pennisetum sp.. The isolates of yeasts and bacteria were screened following hypersensitive test on tobacco leaves, direct planting method test on 'Ciherang' rice seed, and hemolysis test on blood agar medium. The isolates were also further assayed for their antagonism through dual culture test, volatile compound test, hyperparasitism test, and chitinolytic activity test. Three isolates of yeast, i.e. Cryptococcus sp., Rhodotorula sp., and Candida sp., and two bacterial isolates, i.e. Bacillus sp. and isolate PPY were identified as potential antagonists of P. oryzae.
\end{abstract}

Key words: chitinolytic, hemolysis test, hyperparasitism, hypersensitive test, volatile compound

*Alamat penulis korespondensi: Departemen Proteksi Tanaman, Fakultas Pertanian, Institut Pertanian Bogor, Jalan Kamper, Kampus IPB Darmaga, Bogor 16680.

Tel: 0251-7533525, Faks : 0251-8629364, Surel: mssinaga@yahoo.com. 


\section{PENDAHULUAN}

Padi merupakan tanaman pangan terpenting di Indonesia. Produktivitas padi belum optimal disebabkan oleh cekaman abiotik maupun biotik. Salah satu faktor biotik ialah penyakit blas yang disebabkan oleh cendawan Pyricularia oryzae yang dapat menyebabkan kehilangan hasil sampai 61\% (Suganda et al. 2016).

Pengendalian penyakit blas yang umum dilakukan ialah penggunaan varietas tahan dan penggunaan fungisida. Penggunaan varietas tahan menjadi kurang efektif karena P. oryzae sangat cepat membentuk ras baru (Reflinur et al. 2005). Varietas padi IR64 yang awalnya tahan blas, kini dapat terserang oleh P. oryzae ras 041, 54 043, 051,061, 073, 141, 161, dan 173 (Yuliani dan Maryana 2014). Upaya lain untuk mengendalikan blas dilakukan menggunakan fungisida (Suganda et al. 2016), namun jika tidak tepat justru dapat memicu resistensi patogen. Fungisida blasticidin-S, IBP, dan carproapamid sudah tidak efektif mengendalikan penyakit blas karena munculnya ras patogen yang lebih resisten (Takagi et al. 2004). Fungisida juga meninggalkan residu yang berbahaya bagi mikroorganisme dan organisme nontarget.

Dewasa ini, banyak upaya pengembangan pengendalian alternatif yang efektif dan lebih ramah lingkungan, misalnya dengan memanfaatkan agens antagonis, baik bakteri maupun khamir. Keberadaan mikroorganisme pada daun (filoplan) dapat berpengaruh positif terhadap tanaman, misalnya dengan mencegah kolonisasi patogen pada daun, memacu pertumbuhan tanaman, memiliki mekanisme antagonis, dan menginduksi ketahanan tanaman (Dees et al. 2015).

Bakteri endofit yang diisolasi dari akar padi gogo di Jawa dan Sumatera menunjukkan reaksi antibiosis terhadap Rhizoctonia solani dan $P$. grisea pada medium agar dekstrosa kentang (ADK) dan tryptic soy agar (TSA), serta dapat memacu pertumbuhan akar dan tajuk tanaman padi (Munif et al. 2012). Bakteri rizosfer Bacillus cereus 11UJ memiliki daya hambat yang kuat terhadap P. oryzae (Suryadi et al. 2015). Selain bakteri, cendawan endofit yang diisolasi dari tanaman padi sawah juga mampu menekan perkembangan penyakit blas dengan tingkat penekanan mencapai 70\% (Sucipto et al. 2015). Penelitian ini bertujuan mendapatkan isolat khamir dan bakteri yang berpotensi efektif dalam mengendalikan penyakit blas.

\section{BAHAN DAN METODE}

\section{Isolasi dan Identifikasi Khamir dan Bakteri}

Khamir dan bakteri diisolasi dari daun Digitaria sp, Panicum sp., dan Pennisetum sp., metode isolasi merujuk pada Hartati et al. (2014). Khamir dan bakteri yang diperoleh disimpan pada medium ADK miring. Identifikasi khamir dan bakteri dilakukan berdasarkan morfologi koloni dan bentuk mikroskopis, karakteristik koloni yang tumbuh juga diamati.

\section{Uji Patogenisitas}

Uji patogenitas dilakukan untuk mengetahui potensi mikroorganisme uji sebagai patogen. Bebarapa uji yang dilakukan ialah uji hiperparasitisme pada daun tembakau, uji tanam langsung (direct planting method-DPM) pada benih padi Ciherang, dan uji hemolisis pada medium agar-agar darah. Masing-masing uji dilakukan dengan 3 kali ulangan.

Mikroorganisme uji dibiakkan pada medium larutan dekstrosa kentang (LDK) dan dikocok dengan kecepatan 120 rpm selama 24 jam. Suspensi mikroorganisme uji disuntikkan pada daun tembakau untuk menentukan hipersensitifnya. Pengamatan gejala nekrosis dilakukan setelah 24 dan 48 jam (Hartati et al. 2014).

Uji DPM dilakukan menggunakan 10 benih padi varietas Ciherang untuk setiap perlakuan. Mikroorganisme uji dibiakkan pada medium ADK 20\%. Benih yang digunakan disterilkan menggunakan $\mathrm{NaOCl} 1 \%$ selama 1 menit, kemudian dibilas dengan akuades steril sebanyak 2 kali. Benih ditanam pada biakan mikroorganisme uji yang berumur 24 jam. Sebagai perlakuan kontrol positif digunakan 
benih padi yang ditanam pada biakan $P$. oryzae berumur 10 hari. Kontrol negatifmenggunakan benih yang ditanam pada medium ADK 20\% tanpa biakan $P$. oryzae. Pengamatan dilakukan selama 10 hari (Sucipto 2016).

Uji aktivitas hemolisis dilakukan berdasarkan metode Manns et al. (1994). Mikroorganisme uji diinokulasi pada medium agar-agar darah dan diinkubasi selama 48 jam pada suhu ruang. Zona bening atau hijau kecokelatan yang terbentuk di sekitar biakan isolat menandakan mikroorganisme uji yang diinokulasikan mampu menguraikan sel darah (hemolisis) yang terdapat pada medium, sehingga berpotensi sebagai patogen bagi mamalia.

\section{Uji Keefektifan Mikroorganisme Uji terhadap P. oryzae secara in Vitro}

Dalam penelitian ini dilakukan beberapa metode pengujian untuk mengetahui keefektifan mikroorganisme uji dalam menekan P. oryzae. Beberapa pengujian yang dilakukan, yaitu uji hiperparasitisme, uji kultur ganda, uji produksi senyawa volatil, dan uji aktivitas kitinolitik. Setiap pengujian dilakukan dengan 3 kali ulangan.

Uji hiperparasitisme dilakukan pada medium ADK 20\% yang dipotong berukuran $2 \mathrm{~cm} \times 2 \mathrm{~cm}$ dan diletakkan di atas kaca objek. Potongan biakan $P$. oryzae diletakkan di atas blok ADK 20\% sementara biakan mikroorganisme uji digores melingkari potongan $P$. oryzae, kemudian ditutup menggunakan kaca tutup dan diinkubasi selama 7 hari. Pengamatan terjadinya interaksi hiperparasitisme dilakukan menggunakan mikroskop (Hartati et al. 2014).

Uji kultur ganda dilakukan dengan menggoreskan biakan mikroorganisme uji secara melintang di bagian tengah medium ADK di cawan petri. Potongan biakan $P$. oryzae diletakkan di sisi kanan dan kiri goresan mikroorganisme uji dengan jarak $\pm 2 \mathrm{~cm}$. Pertumbuhan koloni $P$. oryzae diamati setiap hari selama 10 hari. Kemampuan penghambatan mikroorganisme uji dihitung menggunakan rumus:

$$
\mathrm{THR}_{\mathrm{dc}}=\frac{\mathrm{R} 1-\mathrm{R} 2}{\mathrm{R} 1} \times 100 \% \text {, dengan }
$$

THR $_{\mathrm{dc}}$, tingkat hambatan relatif (\%) pada uji kultur ganda; R1, diameter pertumbuhan $P$. oryzae pada kontrol (mm); dan R2, diameter pertumbuhan $P$. oryzae pada perlakuan (mm) (Hartati et al. 2014).

Uji produksi senyawa volatil dilakukan dengan menangkupkan cawan petri berisi koloni P. oryzae ke atas cawan petri yang berisi koloni mikroorganisme uji. Pertumbuhan $P$. oryzae diamati dengan mengukur diameter pertumbuhan koloni P. oryzae selama 10 hari. Kemampuan penghambatan isolat khamir dan bakteri dihitung menggunakan rumus (Hartati et al. 2014):

$$
\mathrm{THR}_{\mathrm{v}}=\frac{\mathrm{dk}-\mathrm{dp}}{\mathrm{dp}} \times 100 \% \text {, dengan }
$$

$\mathrm{THR}_{\mathrm{v}}$, tingkat hambat relatif (\%) isolat khamir dan bakteri pada uji produksi senyawa volatil; $\mathrm{dk}$, diameter P. oryzae pada kontrol $(\mathrm{cm})$; dan $\mathrm{dp}$, diameter $P$. oryzae pada perlakuan $(\mathrm{cm})$.

Uji aktivitas kitinolitik dilakukan dengan menginokulasikan mikroorganisme uji pada medium agar-agar koloidal kitin (colloidal chitin agar-CCA) dan diinkubasi selama 48 jam. Jika ditemukan zona bening di sekitar koloni maka mikroorganisme uji mampu menghasilkan enzim kitinase yang dapat melisis kitin. Indeks kitinolitik dihitung dengan rumus (Hartati et al. 2014):

$$
\Delta \mathrm{Y}=\frac{\mathrm{y}_{2}}{\mathrm{y}_{1}}, \text { dengan }
$$

$\Delta \mathrm{Y}$, indeks kitinolitik; $\mathrm{y}_{1}$, lebar koloni khamir $(\mathrm{mm})$; dan $\mathrm{y}_{2}$, lebar zona bening di sekitar koloni (mm).

\section{Rancangan Percobaan dan Analisis Data}

Uji in vitro dilakukan menggunakan rancangan percobaan acak lengkap dengan 3 ulangan. Data peubah tingkat hambatan relatif pada uji kultur ganda, uji produksi senyawa volatil, serta pertumbuhan padi dianalisis ragam dan perlakuan yang berpengaruh nyata diuji lanjut dengan DMRT pada taraf nyata $5 \%$ menggunakan piranti SAS 9.1. 


\section{HASIL}

Hasil isolasi dari daun Digitaria sp., Pennisetum sp., dan Panicum sp. diperoleh khamir Rhodotorula sp., Cryptococcus sp., Candida sp., serta bakteri Bacillus sp. dan isolat PPY. Hasil uji hipersensitif, uji DPM, dan uji hemolisis menunjukkan bahwa Rhodotorula sp., Cryptococcus sp., Candida sp., Bacillus sp., dan isolat PPY tidak berpotensi sebagai patogen pada tumbuhan maupun mamalia. Khamir dan bakteri tersebut tidak menunjukkan gejala nekrosis pada daun tembakau, tidak membentuk zona bening maupun zona hijau kecokelatan pada medium agar-agar darah, serta tidak menimbulkan gejala nekrosis dan pertumbuhan abnormal pada bibit padi.

Hasil uji pembentukan senyawa volatil menunjukkan bahwa Cryptococcus sp., Candida sp., dan Bacillus sp. memiliki tingkat hambatan relatif tertinggi terhadap koloni P. oryzae (Tabel 1). Hasil uji kultur ganda menunjukkan bahwa isolat PPY bersifat antibiosis pada $P$. oryzae dibuktikan dengan adanya zona bening antara $P$. oryzae dan isolat PPY. Bacillus sp., Cryptococcus sp., Candida sp., dan Rhodotorula sp. dapat menghambat pertumbuhan miselium cendawan $P$. oryzae (Gambar 1).

Hasil uji hiperparasitisme menunjukkan bahwa Rhodotorula sp., Cryptococcus sp, dan Candida sp. dapat memenetrasi hifa $P$. oryzae. Infeksi Rhodotorula sp. menyebabkan hifa membengkak, Cryptococcus sp. menyebabkan hifa mengerut kemudian patah, dan Candida sp. dapat memenetrasi tanpa menyebabkan malformasi hifa. Bacillus sp. menyebabkan hifa lisis. Khamir Rhodotorula sp., Cryptococcus sp, dan Candida sp. dapat mendegradasi kitin yang dibuktikan dengan terbentuknya zona bening di sekitar isolat tersebut pada medium CCA (Gambar 1).

\section{PEMBAHASAN}

Agens hayati memiliki beberapa mekanisme dalam aktivitas biokontrol, di antaranya mencegah kolonisasi patogen pada daun, menginduksi ketahanan tanaman kompetisi nutrisi dan ruang, menekan perkecambahan spora, mengurangi ukuran panjang tabung kecambah, dan memproduksi senyawa volatil. Agens hayati juga mampu menghasilkan metabolit sekunder yang dapat menghambat pertumbuhan patogen (Dees et al. 2015).

Khamir dan bakteri yang diperoleh memiliki kemampuan antagonis yang berbeda. Khamir Cryptococcus sp., Candida sp., dan Rhodotorula sp. dapat menghasilkan senyawa volatil yang menghambat pertumbuhan $P$. oryzae. Cryptococcus magnus, C. curvatus, dan C. terreus dapat menghasilkan senyawa volatil berupa dimethyl disulfide yang merupakan antifungi (Buzzini et al. 2005). Candida intermedia dapat menghasilkan senyawa volatil yang efektif menekan pertumbuhan Botrytis cinerea (Huang et al. 2011).

Selain itu, Cryptococcus sp., Candida sp., dan Rhodotorula sp. dapat merusak hifa $P$. oryzae dengan hiperparasitisme dan menghasilkan enzim kitinase. Candida krusei ATCC 6258 dapat melekat pada Fusarium guttiforme dan menyebabkan hifa menjadi lebih kecil (Korres et al. 2011). Candida

Tabel 1 Mekanisme antagonis khamir dan bakteri terhadap P. oryzae secara in vitro

\begin{tabular}{lcccc}
\hline Isolat & $\begin{array}{c}\mathrm{THR}_{\mathrm{dc}} \\
(\%)^{\mathrm{a}}\end{array}$ & $\begin{array}{c}\mathrm{THR}_{\mathrm{v}} \\
(\%)^{\mathrm{a}}\end{array}$ & Hiperparasitisme & Indeks Kitinolitik \\
\hline Rhodotorula sp. & $13.09 \mathrm{c}$ & $23.64 \mathrm{c}$ & + & 2.93 \\
Cryptococcus sp. & $20.26 \mathrm{c}$ & $68.48 \mathrm{a}$ & + & 2.87 \\
Candida sp. & $19.46 \mathrm{c}$ & $53.33 \mathrm{ab}$ & + & 2.47 \\
Bacillus sp. & $34.51 \mathrm{~b}$ & $40.61 \mathrm{bc}$ & + & 0.00 \\
PPY & $53.97 \mathrm{a}$ & $-4.23 \mathrm{~d}$ & - & 0.00 \\
\hline
\end{tabular}

${ }^{\mathrm{a} A n g k a}$ yang diikuti huruf yang sama pada lajur yang sama menunjukkan tidak berbeda nyata pada uji Duncan $\alpha 5 \%$ ${ }^{\mathrm{b} B a k t e r i}$ epifit dari daun Pennisetum sp. pada medium YMA. 


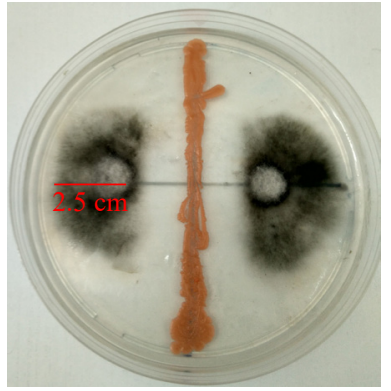

$\mathrm{a}$

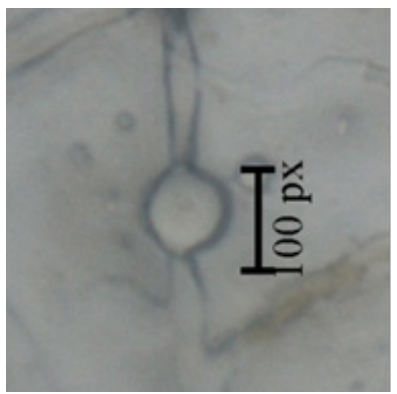

e

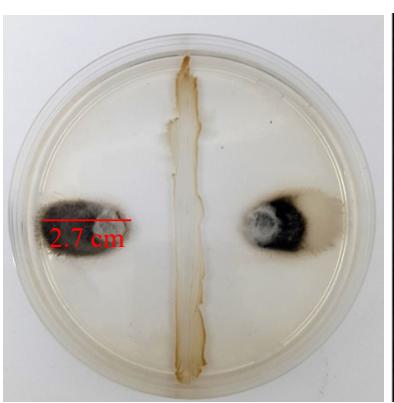

b

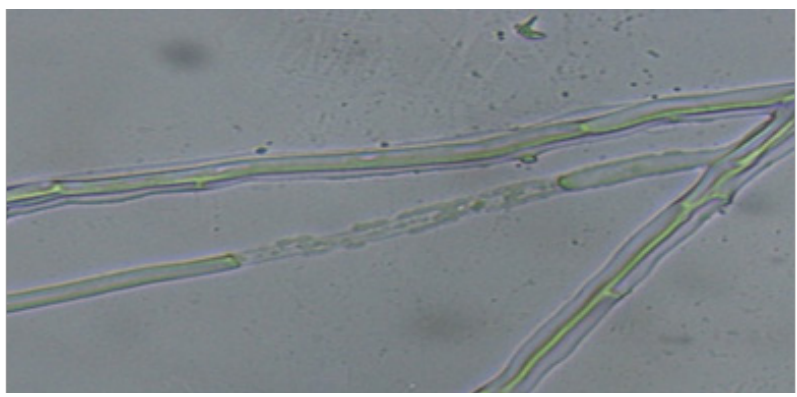

$\mathrm{f}$

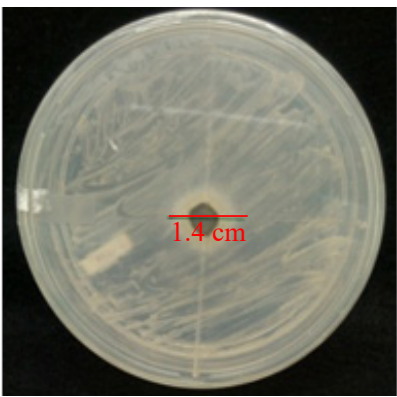

C

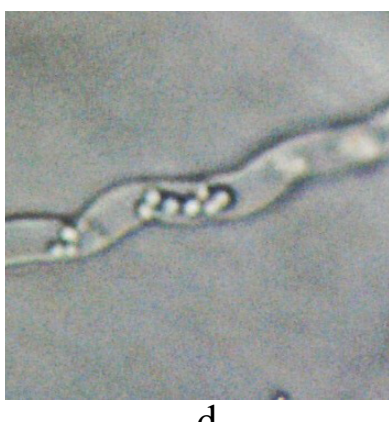

d

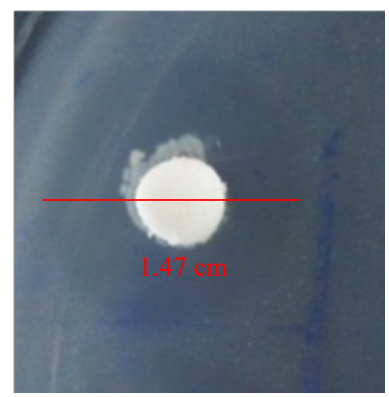

$\mathrm{g}$

Gambar 1 Uji keefektifan mikroorganime uji. a, P. oryzae yang berada di dekat mikroorganisme uji menjadi lebih tipis; b, P. oryzae tidak dapat tumbuh di sekitar isolat PPY; c, Diameter miselium $P$. oryzae lebih kecil daripada kontrol pada uji pembentukan senyawa volatil; d, Candida sp. memenetrasi hifa P. oryzae; e, Rhodotorula sp. menyebabkan hifa P. oryzae membengkak; f, Bacillus sp. menyebabkan hifa P. oryzae lisis; dan g, Rhodotorula sp. mendegradasi kitin yang ditunjukan dengan adanya zona bening pada medium agar-agar koloidal kitin.

saitoana diketahui efektif mengendalikan Botrytis cinerea pada buah apel dengan menghasilkan enzim kitinase dan $\beta-1,3-$ glucanase (El Ghaouth et al. 2003).

Bacillus sp. cukup efektif menekan pertumbuhan $P$. oryzae pada uji kultur ganda dan uji pembentukan senyawa volatil. Meskipun Bacillus sp. tidak menunjukkan aktivitas enzim kitinase pada medium CCA, tetapi Bacillus sp. dapat menyebabkan hifa $P$. oryzae lisis pada uji hiperparasitisme. Bacillus amyloliquefaciens memiliki potensi antagonis untuk mengendalikan Botrytis cinerea pada buah persik (Arrebola et al. 2010). Bacillus subtilis dan Candida sake terbukti efektif dalam menekan embun tepung (Erysiphe betae) dan bercak daun cercospora (Ziedan dan Farrag 2011).

Dapat disimpulkan bahwa Cryptococcus sp., Candida sp., dan Rhodotorula sp. memiliki keefektifan tertinggi dalam menekan $P$. oryzae dengan beberapa mekanisme, yaitu menghasilkan senyawa volatil, hiperparasitisme, dan menghasilkan enzim kitinase. Bacillus sp. cukup efektif dalam menekan P. oryzae pada uji kultur ganda dan uji pembentukan senyawa volatil, serta mampu melisis hifa P. oryzae. Diperlukan penelitian lanjutan untuk menguji keefektifan khamir dan bakteri tersebut dalam di lapangan.

\section{DAFTAR PUSTAKA}

Arrebola E, Sivakumar D, Bacigalupo R, Korsten L. 2010. Combined application of antagonist Bacillus amyloquefaciens and essential oils for the control of peach postharvest diseases. Crop Prot. 29:369377. DOI: https://doi.org/10.1016/j. cropro.2009.08.001.

Buzzini P, Romano S, Turchetti B, Vaughan A, Pagnoni UM, Davoli P. 2005. Production of volatile organic sulfur compounds by basidiomycetous yeast. FEMS Yeast Res. 5:379-385. DOI: https://doi.org/10.1016/j. femsyr.2004.10.011.

Dees MW, Lysoe E, Nordskog B, Brurberg MB. 2015. Bacterial communities associated 
with surfaces of leafy greens: shift in composition and decrease in richness over time. AEM. 81(4):1530-1539. DOI: https://doi.org/10.1128/AEM.03470-14.

El Ghaouth A, Wilson CL, Wisniewski M. 2003. Control of postharvest decay of aple fruit with Candida saitoana and induction of defense responses. $\mathrm{J}$ Phytopathol. 93(3):344-348. DOI: https:// doi.org/10.1094/PHYTO.2003.93.3.344.

Hartati S, Wiyono S, Hidayat SH, Sinaga MS. 2014. Seleksi khamir epifit sebagai agens antagonis penyakit antraknosa pada cabai. J Hort. 24(3):258-265. DOI: https://doi. org/10.21082/jhort.v24n3.2014.p258-265.

Huang R, Li GQ, Zhang J, Yang L, Che HJ, Jiang DH, Huang HC. 2011. Control of postharvest botrytis fruit rot of strawberrry by volatile organic compounds of Candida intermedia. Phytopathology. 101(7):859869. DOI: https://doi.org/10.1094/ PHYTO-09-10-0255.

Korres AMN, Buss DS, Ventura JA, Fernandes PMB. 2011. Candida krusei and Kloeckera apis inhibit the causal agent of pineapple fusariosis, Fusarium guttiforme. Fungal Biol. 115(12):1251-1258.

Manns JM, Mosser DM. Buckley HR. 1994. Production of a hemolytic factor by Candida albicans. Infect Immun. 62:5154-5156.

Munif A, Wiyono S, Suwarno. 2012. Isolasi bakteri endofit asal padi gogo dan potensinya sebagai agens biokontrol dan pemacu pertumbuhan. J Fitopatol Indones. 8(3):57-64. DOI: https://doi.org/10.14692/ jfi.8.3.57.

Reflinur, Bustaman M, Widyastuti U, Aswidinnoor H. 2005. Keragaman genetik cendawan Pyricularia oryzae berdasarkan primer spesifik gen virulensi. J Biotek Pert. 10(2):55-60.

Sucipto I, Munif A, Suryadi Y, Tondok EF. 2015. Eksplorasi cendawan endofit asal padi sawah sebagai agens pengendali penyakit blas pada padi sawah. J Fitopatol Indones. 11(6):211-218. DOI: https://doi. org/10.14692/jfi.11.6.211.

Suganda T, Yulia E, Widiantini F, Hersanti. 2016. Intensitas penyakit blas (Pyricularia oryzae Cav.) pada padi varietas Ciherang di lokasi endemik dan pengaruhnya terhadap kehilangan hasil. J Agr. 27(3):154-159.

Suryadi Y. Samudra IM, Priyatno TP, Susilowati DN, Lestari P, Sutoro. 2015. Aktivitas anticendawan Bacillus cereus 11UJ terhadap Rhizoctonia solani dan Pyricularia oryzae. J Fitopatol Indones. 11(2):35-42. DOI: https://doi. org/10.14692/jfi.11.2.35.

Takagi M, Kaku K, Watanabe S, Kawai K, Shimizu T, Sawada H, Kumakura K, Nagayama K. 2004. Mechanism of resistance to carpropamid in Magnaporthe grisea. Pest Manag Sci. 60:921-926. DOI: https://doi.org/10.1002/ps.896.

Yuliani D, Maryana YE. 2014. Integrasi teknologi pengendalian penyakit blas pada tanaman padi di lahan sub-optimal. Di dalam: Prosiding Seminar Nasional Lahan Suboptimal; 2014 Sep 26-27; Palembang (ID): PUR-PLSO Universitas Sriwijaya.

Ziedan ESHE, Farrag ESH. 2011. Application of yeasts as biocontrol agents for controlling foliar diseases on sugar beet plants. J Agr Tech. 7(6):1789-1799. 